\title{
Protein Starvation and the Small Intestine
}

\author{
III. INCORPORATION OF ORALLY AND \\ INTRAPERITONEALLY ADMINISTERED \\ $l$-LEUCINE $4,5-^{3} \mathrm{H}$ INTO INTESTINAL \\ MUCOSAL PROTEIN OF PROTEIN-DEPRIVED RATS
}

\author{
Jan S. Hirschfield and Fred Kern, Jr. \\ From the Division of Gastroenterology, Department of Medicine, University of \\ Colorado Medical Center, Denver, Colorado 80200
}

\begin{abstract}
A в S T R A C T Weanling rats were fed diets which contained either no protein or $27 \%$ protein. In one experiment after 23-35 days both groups were given $l$-leucine$4,5-{ }^{3} \mathrm{H}$ either intragastrically or intraperitoneally and then sacrificed $24 \mathrm{hr}$ later. In a second experiment animals were given these diets for 21 days and sacrificed 3,6 , or $12 \mathrm{hr}$ after either intragastric or intraperitoneal administration of the labeled leucine. In both experiments the intestinal mucosa of proximal and distal segments of the small intestine was scraped, weighed, the protein concentration measured, and the specific activty of the mucosal protein was determined.
\end{abstract}

The wet weight of the mucosa and the protein concentration of the mucosa were significantly greater in the control animals than in the protein-depleted animals. The mucosal protein per $100 \mathrm{~g}$ of body weight was the same in the protein-deprived and the control groups. The specific activity of the intestinal mucosal protein was higer in the protein-deprived animals than in the control animals.

In the protein-deprived animals the proximal segment incorporated more radioactive amino acid into mucosal protein than did the distal segment at 3,6, 12, and $24 \mathrm{hr}$ after the amino acid was given by mouth. A similar difference was found between the proximal and distal segments of the control animals $6 \mathrm{hr}$ after oral adminisstration of $l$-leucine $-{ }^{3} \mathrm{H}$. On the other hand, when the $l$-leucine- ${ }^{3} \mathrm{H}$ was given intraperitoneally to both groups

Presented in part at meetings of the American Federation for Clinical Research, Atlantic City, May 1966, and the Gastroenterological Research Forum, Chicago, May 1966.

Dr. Hirschfield's present address is University of Louisville School of Medicine, Louisville, $\mathrm{Ky}$.

Received for publication 22 November 1968 and in revised form 21 February 1969. of animals there was no difference between proximal and distal small intestine. These findings suggest that intestinal mucosal protein can be synthesized directly from intraluminal amino acids, especially during protein deprivation, and that endogenous intraluminal protein might be important in the nutrition of the small intestinal mucosa.

\section{INTRODUCTION}

The small intestinal mucosa resists atrophy during protein deprivation for a longer time than many other tissues (1-3). Recent studies have shown that the jejunal mucosa is even more resistant than the ileal mucosa $(4,5)$. The epithelium of the intestinal mucosa has a rapid turnover rate, which is reduced during protein deficiency (6) and starvation (7), but nevertheless this tissue synthesizes a large amount of protein each day $(8,9)$. It is probably because of the rapid rate of growth that the small intestinal mucosa of the proteindeficient animal incorporates parenterally administered radioactive amino acids into protein more efficiently than other tissues $(3,8,10,11)$.

The mechanism by which the intestinal mucosa, especially in the proximal small intestine, resists atrophy during protein depletion is unknown. The lumen of the small intestine normally contains a large concentration of amino acids derived from the diet and from endogenous protein (12). Such amino acids might be preferentially utilized for protein synthesis by the intestinal mucosa. The availability of endogenous amino acids for nutrition of the intestinal mucosa might be partly responsible for the ability of the mucosa to resist atrophy during protein starvation. Furthermore, the greater 
resistance of the jejunum might be because the jejunum has the first opportunity to absorb and utilize endogenous amino acids present in the lumen.

To evaluate these ideas the following experiments were performed.

\section{METHODS}

First experiment. 21 day old male, albino (Holtzman) rats, mean weight $50 \mathrm{~g}$, were separated into two feeding groups. The control group was fed a synthetic diet in a powdered form containing $27 \%$ vitamin-free casein, ${ }^{1} 59 \%$ corn starch, $10 \%$ vegetable oil, $4 \%$ salt mixture, ${ }^{2}$ and $0.5 \%$ vitamin diet fortification mixture. ${ }^{1}$ The experimental group was offered a protein-free diet in a powdered form containing $70 \%$ cornstarch, $16 \%$ cellulose, $10 \%$ vegetable oil, $4 \%$ salt mixture, ${ }^{2}$ and $0.5 \%$ vitamin diet fortification mixture. ${ }^{1}$ The animals were housed individually in wire cages and were weighed weekly. A few protein-deprived animals died before completion of the experiment; all survivors were studied. After dietary periods varying from 23 to 35 days each of the above groups was divided into two subgroups. One subgroup was given $10 \mu \mathrm{c} / 100 \mathrm{~g}$ of body weight of $l$-leucine- $-4,5-{ }^{8} \mathrm{H}$ (specific activity $5 \mathrm{c} / \mathrm{mmole}^{3}$ ) by stomach tube (for convenience, referred to as "oral") and the other subgroup was given the same dose of tritium-labeled leucine by intraperitoneal injection. The animals were not fasted before the administration of the leucine. They were then returned to their cages and were allowed food and water ad lib. 24 hr. later they were killed by a blow on the head and jugular exsanguination. The small intestine from the distal attachment of the pancreas on the duodenum to the ileo-cecal valve was removed and rinsed with cold $0.9 \%$ saline until free of contents. Excess saline was carefully drained. The small intestine was divided into three equal segments and the proximal third and the distal third were utilized in the experiment. The proximal segment will be referred to as jejunum and the distal segment, ileum. The mucosa of each was scraped with a glass slide, drained, and the scrapings placed into tared modified Potter-Elvehjem tubes and weighed. It was then homogenized in physiologic saline. An aliquot was used for protein determination by a modified Folin phenol reagent method $(13,14)$. The remainder of the homogenate was added to $15 \%$ trichloracetic acid (TCA) and after standing in a cold room overnight, the precipitate was centrifuged and extracted with ethanoldiethyl ether $(2: 1)$ at $60^{\circ} \mathrm{C}$, and with $10 \%$ TCA at $90^{\circ} \mathrm{C}$. The precipitates were then washed with ethanol, ethanolether mixture, and ether and then were dried in air (15). The dried precipitate was dissolved in $1 \mathrm{ml}$ of $\mathrm{N} \mathrm{NaOH}$ at $60^{\circ} \mathrm{C}$ and duplicate $0.1 \mathrm{ml}$ aliquots were added to $5 \%$ $\mathrm{Cab}-\mathrm{O}-\mathrm{Sil}^{*}$ in a toluene and dioxane phosphor (16) and the radioactivity assayed in a liquid scintillation spectrometer."

Second experiment. The same procedures were employed as before except: (a) the dietary periods were 21 days; (b) after oral or intraperitoneal administration of the tritium-labeled leucine the animals were sacrificed at intervals of 3,6 , and $12 \mathrm{hr}$; and (c) the small intestine was divided into four equal segments instead of three and again only the proximal and distal segments were studied.

\footnotetext{
${ }^{1}$ Nutritional Biochemicals Corporation, Cleveland, Ohio.

${ }^{2}$ Salt Mixture USP XIV, Nutritional Biochemical Corporation.

${ }^{3}$ New England Nuclear Corp., Boston, Mass.

* Packard Instrument Co., LaGrange, Ill.
}

Statistics. Range of each value given is represented as standard error of the mean (SEM) and statistical evaluation was by the $t$ test (17).

\section{RESULTS}

\section{First experiment}

General. The experimental animals lost weight especially during the 1 st $2 \mathrm{wk}$, and weighed $34 \pm 2 \mathrm{~g}$ at sacrifice. They lost muscle mass and hair. They appeared pale, but ate and moved about freely. The control group gained weight consistently and weighed $197 \pm 9 \mathrm{~g}$ at sacrifice (Fig. 1).

Mucosal weight. In the control rats the jejunal mucosa weighed $1.60 \pm 0.12 \mathrm{~g}$ and the ileal mucosa weighed $1.19 \pm 0.03 \mathrm{~g}$ (Table I). In the protein-deprived animals the jejunal weights were $0.30 \pm 0.08 \mathrm{~g}$ and the ileal, 0.25 $\pm 0.08 \mathrm{~g}$. The jejunal mucosa was significantly heavier than the ileal only in the control animals $(P<0.05)$.

Mucosal protein concentration. The mucosa protein concentration (mg protein per $100 \mathrm{mg}$ mucosa) of the control jejunum was $6.16 \pm 0.33 \mathrm{mg}$ and of the control ileum was $5.72 \pm 0.25 \mathrm{mg}$. In the protein-depleted rats the jejunal protein concentration was $4.98 \pm 0.16 \mathrm{mg}$ and the ileal was $4.44 \pm 0.02 \mathrm{mg}$, (Table I). The differences between control and experimental groups was significant for both parts of the intestine $(P<0.001)$ but within each group the jejunal and ileal protein concentration did not differ significantly.

Mucosal protein per $100 \mathrm{~g}$ body weight. In the jejunum of the control animals the mucosal protein per $100 \mathrm{~g}$ body weight was $54.6 \pm 5.6 \mathrm{mg}$ and in the ileum $36.7 \pm 3.5 \mathrm{mg}(P<0.02)$. In the protein-deprived rats the jejunal mucosal protein was $44.5 \pm 3.3 \mathrm{mg}$ and in the ileum, $31.9 \pm 2.4 \mathrm{mg}$ per 100 gram body weight $(P<$ 0.005 ) (Table I). When the same segments in the control and protein-free animals were compared, they were not significantly different.

Specific activity of the intestinal mucosal protein. The specific activity of the intestinal mucosal protein is expressed as disintegrations per minute $\times 10^{3}$ per milligram of protein (Fig. 2). Regardless of the route of administration of the tritiated leucine the specific activity in the experimental animals was higher than that of the controls $(P<0.001)$. In the control group the specific activity of the mucosal protein of the jejunum did not differ significantly from that of the ileum after either oral or intraperitoneal administration. In the experimental animals, however, the specific activity of the intestinal mucosal protein was affected by the route of administration. When the tritiated leucine was given orally the specific activity of the jejunal mucosa was $13.78 \pm 2.44$ and the specific activity of the ileal mucosa was $9.55 \pm 1.38(P<0.1)$. On the other hand when the radioactive amino acid was given intraperitoneally the 


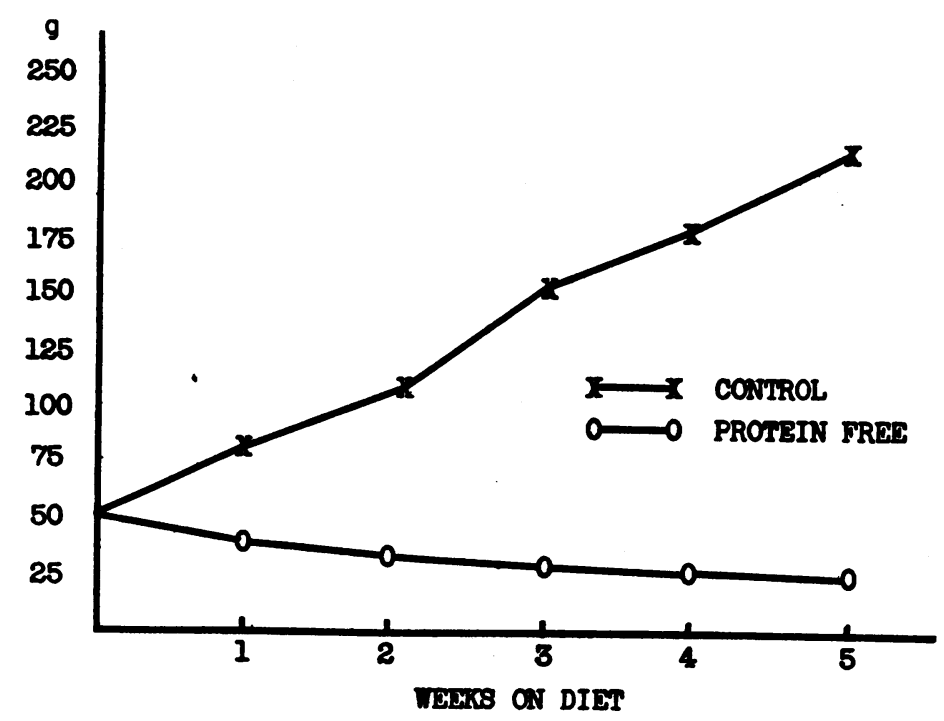

FIgURE 1 Growth curves for control and protein-deprived rats, experiment 1 . Animals were $3 \mathrm{wk}$ old at time zero on abscissa.

specific activity of the jejunal mucosa was only 5.27 \pm 0.24 and that of the ileal mucosa was $5.90 \pm 0.59$. In both parts of the intestine the specific activity was significantly greater when the leucine- ${ }^{3} \mathrm{H}$ was given orally. In the jejunum this difference was more definite $(P<$ $0.02)$ than in the ileum $(P<0.05)$. These data were analyzed further in an attempt to clarify the difference produced by the routes of administration.

The ratios of the specific activity of the jejunal mucosal protein to that of the ileal mucosal protein were compared (Table II). In the protein-deprived group this ratio was greater after oral than after intraperitoneal leucine administration $(P<0.05)$. The ratio in the control animals was the same despite the method of administration. When the control and protein-depleted animals were compared the jejunal/ileal ratio did not differ significantly.

\section{Second experiment}

After 21 days of the dietary regimen the changes in body weight were similar to those found in the first experiment. The mucosa of both parts of the intestine weighed less than in the first experiment because the animals were smaller, and only a quarter, not a third, of the

TABLE I

Effect of Protein Starvation on Intestinal Mucosal Weight and Mucosal Protein*

\begin{tabular}{|c|c|c|c|c|c|c|c|c|}
\hline & \multicolumn{2}{|c|}{ Mucosal weight } & \multicolumn{2}{|c|}{ Protein concentration } & \multicolumn{2}{|c|}{$\begin{array}{l}\text { Total protein in } \\
\text { mucosa scraped }\end{array}$} & \multicolumn{2}{|c|}{ Mucosal protein } \\
\hline & $C \ddagger$ & PF\& & $C \ddagger$ & PF\& & $C \ddagger$ & PF $\&$ & $\mathrm{C} \ddagger$ & PF 8 \\
\hline Experiment $1 \|$ & \multicolumn{2}{|c|}{$g$} & \multicolumn{2}{|c|}{$\mathrm{mg} / 100 \mathrm{mg}$ mucosa } & \multicolumn{2}{|c|}{$m g$} & \multicolumn{2}{|c|}{$m g / 100 \mathrm{~g}$ body $w t$} \\
\hline $\begin{array}{l}\text { Jejunum } \\
\text { Ileum }\end{array}$ & $\begin{array}{l}1.60 \pm 0.12 \\
1.19 \pm 0.03\end{array}$ & $\begin{array}{l}0.30 \pm 0.08 \\
0.25 \pm 0.08\end{array}$ & $\begin{array}{l}6.16 \pm 0.33 \\
5.72 \pm 0.25\end{array}$ & $\begin{array}{l}4.98 \pm 0.16 \\
4.44 \pm 0.02\end{array}$ & $\begin{array}{l}96 \pm 9 \\
65 \pm 5\end{array}$ & $\begin{array}{l}15 \pm 1.5 \\
11 \pm 0.9\end{array}$ & $\begin{array}{l}54.6 \pm 5.6 \\
36.7 \pm 3.5\end{array}$ & $\begin{array}{l}44.5 \pm 3.3 \\
31.9 \pm 2.4\end{array}$ \\
\hline \multicolumn{9}{|l|}{ Experiment $2 \mathbb{T}$} \\
\hline $\begin{array}{l}\text { Jejunum } \\
\text { Ileum }\end{array}$ & $\begin{array}{l}0.88 \pm 0.05 \\
0.68 \pm 0.03\end{array}$ & $\begin{array}{l}0.29 \pm 0.01 \\
0.21 \pm 0.02\end{array}$ & $\begin{array}{l}6.09 \pm 0.13 \\
5.53 \pm 0.27\end{array}$ & $\begin{array}{l}5.26 \pm 0.20 \\
4.43 \pm 0.22\end{array}$ & $\begin{array}{l}53 \pm 2 \\
40 \pm 3\end{array}$ & $\begin{array}{r}15 \pm 1.0 \\
9 \pm 1.0\end{array}$ & $\begin{array}{l}32.4 \pm 1.5 \\
24.2 \pm 2.0\end{array}$ & $\begin{array}{l}43.3 \pm 3.0 \\
26.2 \pm 3.0\end{array}$ \\
\hline
\end{tabular}

* All values mean \pm SE.

$\ddagger \mathrm{C}=$ normal protein diet.

\& $\mathrm{PF}=$ Protein-free diet.

$\|$ Experiment 1 : control $n=15$; protein-free $n=17$.

I Experiment 2: control $n=12$; protein-free $n=18$. 
PROTEIN DEPRIVED

CONTROL

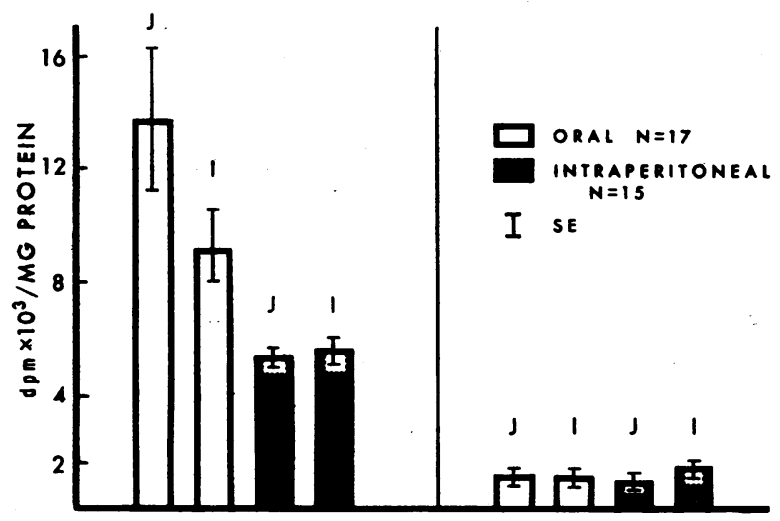

FIGURE 2 Specific activity (SA) of intestinal mucosal protein of rat jejunum (J) and ileum (I) $24 \mathrm{hr}$ after oral or intraperitoneal administration of $l$-leucine-4,5- ${ }^{8} \mathrm{H}$ in control and protein-deprived animals, experiment 1 . SA is expressed as disintegrations per minute per milligram of protein. SA was greater in protein-deprived rats than in control rats. In the protein-starved animals the SA was significantly greater in both intestinal segments when the radioactive amino acid was given orally than when it was given parenterally:

intestine was scraped. The jejunal mucosal weights were significantly heavier than the ileal weights in both control and protein-deprived groups $(P<0.001)$ (Table
TABLE II

Experiment 1: Ratio of Jejunal Mucosal Protein Specific Activity to Ileal Mucosal Protein Specific Activity

\begin{tabular}{|c|c|c|c|}
\hline & \multicolumn{3}{|c|}{ Route of administration of 4,5 -leucine-2 $\mathrm{H}$} \\
\hline & Oral & Intraperitoneal & $P$ \\
\hline Control & 1.12 & 0.98 & 0.8 \\
\hline Protein deprived & 1.45 & 0.90 & $<0.05$ \\
\hline$P$ & 0.4 & 0.9 & \\
\hline
\end{tabular}

I). The protein concentration was higher in the mucosa of the controls for both parts of the intestine, as in the first experiment $(P<0.01)$. No significant difference existed between the mucosal protein per $100 \mathrm{~g}$ body weight of the two groups in either the jejunum or ileum $(P<0.25)$.

Specific activity of intestinal mucosal protein. The specific activity of the intestinal mucosal protein at 3 , 6 , and $12 \mathrm{hr}$ after the administration of the radioactive amino acid was greater in the protein-deprived animals (Fig. 3) $(P<0.001)$. In the control animals there was no difference in specific activity between the jejunal and ileal intestinal mucosal protein at any time after the intraperitoneal administration of the amino acid. After oral administration, however, at $6 \mathrm{hr}$ the jejunum had a significantly higher specific activity $(P<0.05)$. There

ORAL

INTRAPERITONEAL

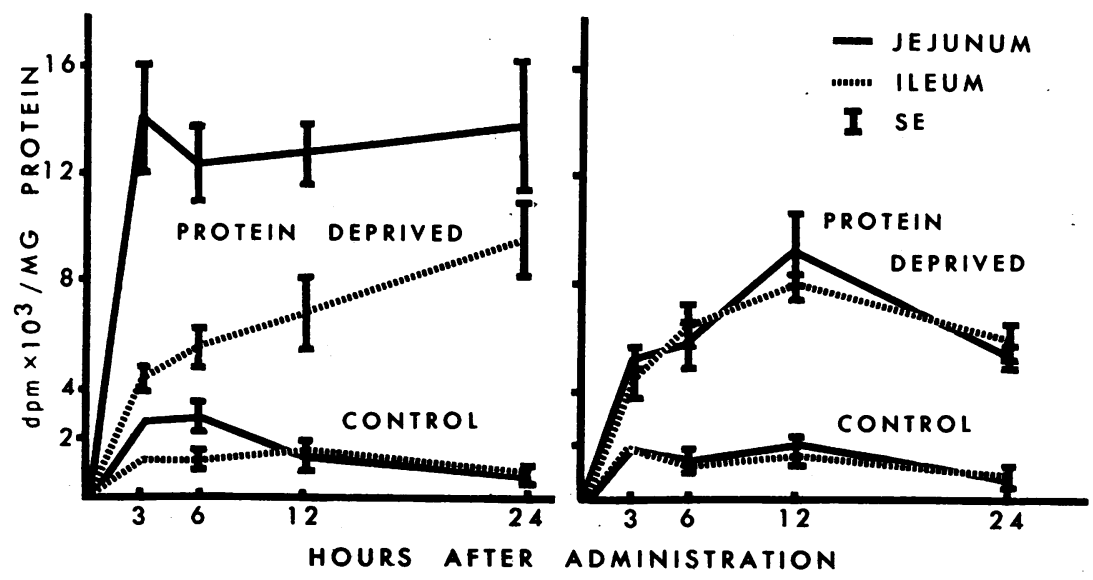

FIGURE 3 Specific activity (SA) of intestinal mucosal protein in jejunum and ileum of control and protein-deprived rats given $l$-leucine $-4,5-{ }^{3} \mathrm{H}$ either orally or by intraperitoneal injection. Values given for 3,6 , and $12 \mathrm{hr}$ after the administration of $l$-leucine-4,5- ${ }^{8} \mathrm{H}$ are from experiment 2 . The 24 -hr values are from experiment 1 . The SA is always greater in the protein-deprived rats than in control rats. (The upper lines represent protein-deprived rats.) In the protein-deprived rats the SA of the jejunum is higher when the radioactive amino acid is given orally than when it was given intraperitoneally. There is a significant difference between jejunal and ileal SA in the protein-deprived rats 3,6 , and $12 \mathrm{hr}$ after oral administration of the radioactive leucine. There is no difference between jejunal and ileal SA in the protein-deprived rats after parenteral administration of the radioactive leucine. 
was no jejuno-ileal difference at 12 or $24 \mathrm{hr}$. In the protein-depleted group given the tritiated leucine orally the specific activity of the intestinal mucosal protein was greater in the jejunum than in the ileum at 3, 6, and 12 hr after administration $(P<0.01)$. However, after the intraperitoneal administration of the radioactive amino acid the jejunal mucosal protein specific activity was always the same as the ileal.

\section{DISCUSSION}

The significance of the marked difference in the mucosal uptake and incorporation into protein of the labeled leucine between the control animals and the proteindepleted animals cannot be assessed from these experiments. The size of the circulating amino acid pool was not measured, but it was probably smaller in the proteindepleted rats. When this pool was labeled with leucine- ${ }^{3} \mathrm{H}$ its specific activity would be considerably higher than the control amino acid pool, making conclusions about differences in rate of protein synthesis impossible. Attention is therefore directed to the differences between the jejunum and ileum within the same experimental group, especially as influenced by the route of administration of the leucine $-{ }^{3} \mathrm{H}$. The studies show that when leucine $-{ }^{3} \mathrm{H}$ was administered orally it was incorporated into jejunal mucosal protein to a much greater extent than into ileal mucosal protein. This difference was greatly exaggerated in the protein-depleted rat and was not present when the leucine ${ }^{8} \mathrm{H}$ was administered parenterally. These findings are relevant to understanding the effects of protein depletion on the intestinal mucosa.

Nutritional protein deficiency in humans and in experimental animals causes morphologic and biochemical changes that have been extensively studied $(1,2,18-25)$. In most tissues atrophy occurs, but the intestinal mucosa remains normal longer than most others $(2,3,22)$. As the protein deprivation progresses, the muscle of the small intestine atrophies and the glandular crypts in the mucosa become thinner $(2,4,23)$, mitoses decrease (6), and DNA synthesis slows (26). Atrophy of the mucosal villi begins later and progresses at a variable rate depending somewhat on the species $(4,5,22)$. In the human careful evaluation of mucosal villous changes in pure protein starvation have not been made. Recently some observers, but not all, have noted earlier and more severe atrophy in the ileum than in the jejunum in the monkey and the rat $(4,5)$. The individual epithelial cells appear normal by light miscrocospy. Takano has described atrophy of the microvilli in the rat (23), but in our studies the microvilli and other fine structural features of both jejunum and ileum appear normal after prolonged (45 days) protein deprivation (5). The activity of the disaccharidases, enzymes located in or on the microvilli, was also unaffected by protein depletion (27).
During normal nutrition the small intestine has a very rapid rate of protein synthesis $(3,9,10,28)$, and this synthesis rate is not slowed markedly during protein depletion $(3,11,21,24)$. After prolonged protein starvation parenterally administered radioactive amino acids are incorporated into the protein of the small intestinal mucosa to a greater extent than in any other organ $(8,11,21)$. This ability of the small intestine to maintain its capacity for protein synthesis was confirmed. The total mucosal protein per unit body weight was not decreased by a protein-free diet; the protein concentration, however, was decreased, an effect which might have been due to an increased amount of mucosal water.

In the earlier studies of the effect of protein depletion upon the incorporation of radioactive amino acids into intestinal mucosal protein, the amino acids were always given intraperitoneally $(3,8,10,11,21)$ and it was found that there was more incorporation of the amino acid into small intestinal protein than in other tissues, and more than in the protein-fed animals. In the present study, oral administration of the amino acid showed an even greater difference between protein-deprived and control animals. This difference suggests that the small intestine, particularly the proximal portion, maintains its protein content and resists atrophy during protein deprivation because it has the first opportunity to utilize amino acids absorbed from the lumen. Such amino acids can only be derived only from endogenous sources during protein deprivation. Nasset and Ju have shown that the endogenous protein content of the normal small intestinal lumen is two to three times that of the dietary intake (29). The endogenous protein is derived from gastric, pancreatic, and intestinal secretions and from cell desquamation (12). During protein deficiency the endogenous protein is reduced $(30,31)$ because of decreased pancreatic enzyme secretion (32) and decreased gastrointestinal cell turnover rate (6). Nevertheless, considerable protein is still present within the lumen $(30,31)$, and if this protein is digested and absorbed it would be available for incorporation into mucosal protein.

Our findings demonstrate that the intestinal cell utilizes amino acids absorbed from the lumen to a greater degree than those supplied by a systemic route. The difference between the jejunal and ileal morphology in animals fed a protein-free diet might be directly related to this finding. The proximal small intestine has available to it more amino acids than the distal; thus by efficient recycling of the endogenous amino acids it can sustain itself longer than the distal small intestine. The observation that at various times after oral administration more radioactive leucine was incorporated into the mucosal protein of the jejunum than of the ileum is consistent with this interpretation. On the other hand, there was no difference between jejunum and ileum when 
the leucine was given by the intraperitoneal route. A similar mechanism is suggested even during normal nutrition by the finding in control rats that the jejunum had a significantly higher specific activity than the ileum $6 \mathrm{hr}$ after the oral administration of the tritium-labeled leucine, wheeras there was no jejuno-ileal difference after intraperitoneal administration of the labeled amino acid.

\section{ACKNOWLEDGMENTS}

This work was supported in part by an NIH Training Grant in Gastroenterology, TI AM-5122, and in part by the Institutional Cancer Grant of the American Cancer Society.

\section{REFERENCES}

1. Adams, C. W., V. S. Fernand, and H. Schnieden. 1958. Histochemistry of a condition resembling kwashiorkor produced in rodents by a low protein-high carbohydrate diet. Brit. J. Exp. Pathol. 39: 393.

2. Deo, M. G., S. K. Sood, and V. Ramalingaswami. 1965. Experimental protein deficiency. Arch. Pathol. 80: 14.

3. Lipkin, M., and H. Quastler. 1962. Studies of protein metabolism in intestinal epithelial cells. J. Clin. Invest. 41: 646 .

4. Deo, M. G., and V. Ramalingaswami. 1964. Absorption of $\mathrm{Co}^{\mathrm{s}}$ labelled cyanocobalamin in protein deficiency. An experimental study in the Rhesus monkey. Gastroenterology. 46: 167.

5. Hill, R. B., Jr., J. Prosper, J. S. Hirschfield, and F. Kern, Jr. 1968. Protein starvation and the small intestine. I. The growth and morphology of the small intestine in weanling rats. Exp. Mol. Pathol. 8: 66.

6. Deo, M. G., and V. Ramalingaswami. 1965. Reaction of the small intestine to induced protein malnutrition in rhesus monkeys. A study af cell population kinetics in the jejunum. Gastroenterology. 49: 150.

7. Hooper, C. S., and M. Blair. 1958. The effect of starvation on epithelial renewal in the rat duodenum. Ex'p. Cell Res. 14: 175.

8. Schreier, K., and C. Kazasis. 1960. Influence of different types of malnutrition on the ${ }^{16} \mathrm{C}$-lysine metabolism in young rats. Nature (London). 187: 1117.

9. Dawson, R., and E. S. Holdsworth. 1962. An investigation into protein digestion with ${ }^{14} \mathrm{C}$-labelled protein. Brit. J. Nutr. 16: 13.

10. Leblond, C. P., N. B. Everett, and B. Simmons. 1957. Sites of protein synthesis as shown by radioautography after administration of $\mathrm{S}^{35}$ labelled methionine. Amer. J. Anat. 101: 225 .

11. Stenram, W. 1962. Radioautographic studies with methionine- ${ }^{8} \mathrm{H}$ and Cytidine ${ }^{3} \mathrm{H}$ on protein deficiency in mice and rats with special reference to liver cells. Exp. Cell Res. 26: 485 .

12. Nasset, E. S. 1965. Role of the digestive system in protein metabolism. Fed. Proc. 24: 953.

13. Lowry, O. H., N. J. Rosebrough, A. L. Farr, and R. J.
Randell. 1951. Protein measurement with the Folin Phenol Reagent. J. Biol. Chem. 193: 265.

14. Oyama, V. I., and H. Eagle. 1956. Measurement of cell growth in tissue culture with a phenol reagent (FolinCiocalteau). Proc. Soc. Exp. Biol. Med. 91: 305.

15. Saunders, S. J., and K. J. Isselbacher. 1965. Inhibition of intestinal amino acid transport by hexoses. Biochim. Biophys. Acta. 102 : 397.

16. Tye, R., and J. D. Engel. 1965. Liquid scintillation counting of carbon-14 in aqueous digests of whole tissues. Anal. Chem. 37: 1225.

17. Croxton, F. E. 1953. Elementary Statistics with Applications in Medicine. Prentice-Hall Inc., Englewood Cliffs, N. J. 327.

18. Scrimshaw, N. S., M. Behar, C. Pérez, and F. Viteri. 1955. Nutritional problems of children in Central America and Panama. Pediatrics. 16: 378.

19. Price, R. W. 1962. Effects of dietary protein level and starvation on the mucosal surface of the small intestine. Aerosp. Med. 33: 42.

20. Kershaw, T. G., K. D. Neame, and G. Wiseman. 1960. The effect of semistarvation on absorption by the rat small intestine in vitro and in vivo. J. Physiol. 152: 182.

21. Muramatsu, K., T. Sato, and K. Ashida. 1963. Dietary protein level and the turnover rate of tissue proteins in rats. J. Nutr. $81: 427$.

22. Platt, B. S., C. R. C. Heard, and R. J. C. Stewart. 1964. The effects of protein calorie deficiency on the gastrointestinal tract. In The Role of the Gastrointestinal Tract in Protein Metabolism. H. N. Munro, editor. F. A. Davis Company, Philadelphia. 227.

23. Takano, J. 1964. Intestinal changes in protein-deficient rats. Exp. Mol. Pathol. 3: 224.

24. Waterlow, J. 1959. Effect of protein depletion on the distribution of protein synthesis. Nature (London). 184: 1875.

25. Tandon, B. N., M. L. Magotra, A. K. Saraya, and V. Ramalingaswami. 1968. Small intestine in protein malnutrition. Amer. J. Clin. Nutr. 21: 813

26. Munro, H. N., and D. M. Goldberg. 1964. The effect of protein intake on the protein and nuclei acid metabolism of the intestinal mucosal cell. In The Role of the Gastrointestinal Tract in Protein Metabolism. H. N. Munro, editor. F. A. Davis Company, Philadelphia. 189.

27. Prosper, J., R. L. Murray, and F. Kern, Jr. 1968. Protein starvation and the small intestine. II. Disaccharidase activities. Gastroenterology. 55: 223.

28. Shorter, R. G., and B. Creamer. 1962. Ribonucleic acid and protein metabolism in the gut. Part 1 . Observations in gastro-intestinal cells with rapid turnover. Gut. 3: 118.

29. Nasset, E. S., and J. S. Ju. 1961. Mixture of endogenous and exogenous protein in the alimentary tract. $J$. Nutr. $74: 461$.

30. Ju, J. S., and E. S. Nasset. 1959. Changes in total nitrogen content of some abdominal viscera in fasting and realimentation. J. Nutr. 68: 633 .

31. Nasset, E. S., P. Schwartz, and H. V. Weiss. 1955. The digestion of proteins in vivo. J. Nutr. 56: 83.

32. Lemire, S., and F. L. Iber. 1965. Protein malnutrition and pancreatic secretion. Clin. Res. 13: 537. (Abstr.) 